\title{
HUE SHIFT AND BRIGHTNESS ENHANCEMENT OF FLICKERING LIGHT
}

\author{
G. J. C. VAN DER Horst and W. MUIS \\ Physics Laboratory, Dept. of Medical and Physiological Physics, \\ State University, Eisenhowerlaan 4, Utrecht, the Netherlands
}

(Received 30 August 1968 : in revised form 4 December 1968)

\section{INTRODUCTION}

BRIGHTNESs, hue and saturation of stimuli strongly depend on the way in which they àre presented in time. BRÜCKE (1864) was the first to discover that the brightness of an illuminated rotating disk changes when the flicker frequency is varied. After him Bartley and his collaborators have quantified these phenomena by means of numerous experiments.

In addition to these psychophysical experiments VARJÚ (1964) has recently studied this effect by means of the pupillary response.

The work done with black and white disks was called "Brücke-effect". BarTLEY (1961) differentiated this Brücke-effect from the "Bartley-effect" of brightness enhancement obtained with episcoisters. Both effects involve brightness increases with respect to that produced by steady stimulation. We therefore indicate both effects with the term "BrückeBartley-effect".

According to BALL (1964), BALL and BARTLEY (1966) the brightness enhancement is critically dependent upon the spectral composition. They found the greatest enhancements at wavelengths around $500 \mathrm{~nm}$, only at high illuminances. Much more attention has been given to the effects of stimulus wavelength on the BROCA-SULzER (1903) phenomenon (stimulating with single flashes instead of intermittent light). It has been considered that the latter and the Brücke-Bartley effect are probably particular manifestations of the same phenomenon.

Recently SHEPPARD (1968) has presented a general survey of both effects. The main conclusions concerning the Broca-Sulzer phenomenon, though conflicting, are:

The greatest enhancement depends upon the spectral composition, with the maximum in blue light (BrocASULZER, 1903); the rate of ficker for reaching the maximum level is greater for red light than for green light, which in turn is greater than that for blue (PIÉRON, 1929). On the other hand STAINTON (1928) gives evidence that the relative maximum apparent luminosity, as well as the rise times, are independent of wavelength. WASSERMAN (1966a) concludes a maximum enhancement for wavelengths that are perceived as the unique hues.

Stimulating with coloured flickering light causes a hue shift too. Ball and Bartley have reported that beyond $500 \mathrm{~nm}$ the hue is shifting towards an invariant point at $570 \mathrm{~nm}$. These qualitative estimates are also given by VERINGA (1961). Besides a hue shift a change in saturation will occur too. For this happens when one stimulates with red coloured light and with a waveband around $500 \mathrm{~nm}$.

First and foremost we were interested in the effect of brightness and its interaction with the apparent hue of the intermittent light. For this reason we looked for a quantitative description and interpretation of the measured hue shift. Secondly we studied the BrückeBartley effect by varying the stimulus diameter from $3 \mathrm{deg}$ to $5 \mathrm{~min}$ of arc. 


\section{APPARATUS AND PROCEDURE}

The appearance of the actual stimuli is shown in Fig. 1 : The upper one always served as the reference light and the lower one as the flickering test light. In the middle was a fixation point, which was illuminated by the reference light source. Its diameter was $24 \mathrm{~min}$ of arc.

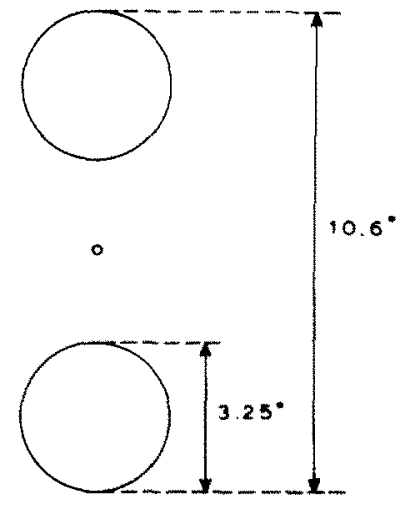

Fig. 1. Appearance of the stimuli to the subject.

The maximum visual angle of the stimuli was $10 \cdot 6^{\circ}$. The stimuli were seen in Maxwellian view. An artificial pupil of $1 \mathrm{~mm}$ dia. was used. The reference light had a fixed luminance and wavelength. The luminance level of the flickering light was controlled by varying the current through the tungsten ribbon-filament lamps. The lightdark ratio was always $1: 1$. The wavelength of the test light was varied by a monochromator. The latter was calibrated with the lines in the mercury, helium and cadmium spectrum. For all these lines the wavelength error was less than $1 \mathrm{~nm}$. The wavelength of the reference light was selected by interference filters (bandwidth $11 \mathrm{~nm}$ ).

The relatively great distance between the two stimuli decreased the chance that mutual inhibition would take place between test and reference light. Moreover, it diminished the influence of stray-light during the dark phase of the flickering cycle.

The observer adapted his eye by viewing the stimuli for about half a minute before the experiment started. The observer's task was to match the reference light by manipulating properly either the luminance or the wavelength of the test light. No limit was set to the duration of the observation, the observer looking continuously at the stimuli while making a match. After having made one match he recorded the readings. The matches were made by the method of adjustment and at least five matches were carried out for each experimental condition.

Our procedure was as follows: the observer varied the experimental parameters in a systematic order. Thus, we chose a wavelength, illumination or target size, and matches were made beginning from the lowest flicker frequency until the highest frequency was reached. Next the wavelength, illumination or target size was varied and the same procedure was repeated. We measured the brightness enhancement at different wavelengths and target sizes (part a and d), by varying the luminance of the test light, the wavelength of the test and reference light patch being the same. The hue shift was measured (part b) by varying the wavelength difference. The luminances were now the same.

\section{EXPERIMENTAL RESULTS}

\section{a. Brightness enhancement at different wavelengths}

The increase in brightness of the intermittent test light was measured at four luminance levels. This luminance range extended from $4800-4.8$ trolands. We performed this series of measurements at three wavelengths, $476 \mathrm{~nm}, 510 \mathrm{~nm}$ and $575 \mathrm{~nm}$, for we knew that at these wavelengths the Bezold -Brücke hue shift is minimal or zero. The brightness enhancement of the flickering light is now reflected in a reduction of the luminance of this light patch to make a match. The reciprocal of this reduction factor is called "brightness gain". The results for observer $\mathrm{H}$ are plotted in Figs. 2-4. In all three graphs we see the same tendencies. There is no essential difference between the three colours used. When the luminance of the stimulus is increased the brightness enhancement and the frequency at which the maximal enhancement occurs, increase too. This confirms the results of RABELO and Grusser (1961) and Wasserman (1966b). SteVEns (1966), interpreting the results of 


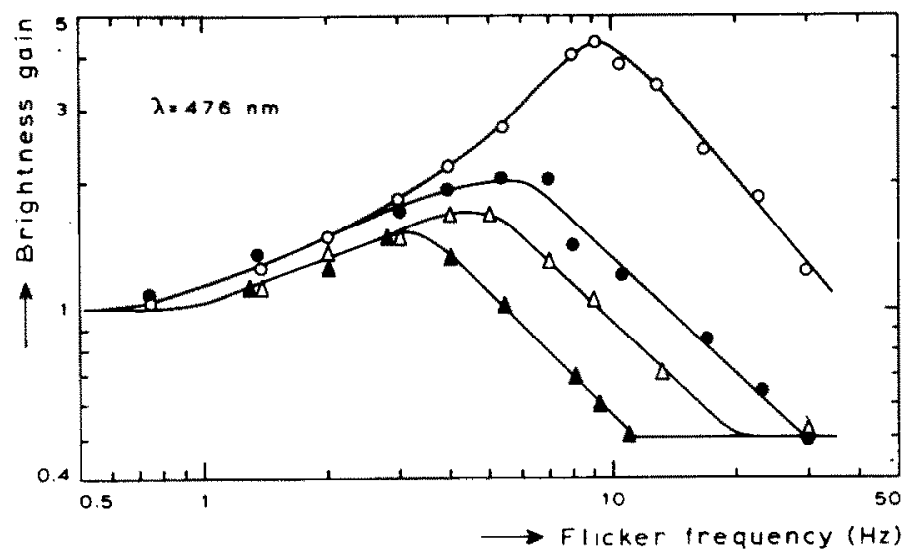

FiG. 2. Brightness enhancement dependent on retinal illuminance at $\lambda=476 \mathrm{~nm}-O-O-4800$ troland; $-480 \mathrm{td} ;-\Delta-48 \mathrm{td} ;-4,8 \mathrm{td}$. Obs $\mathrm{H}$.

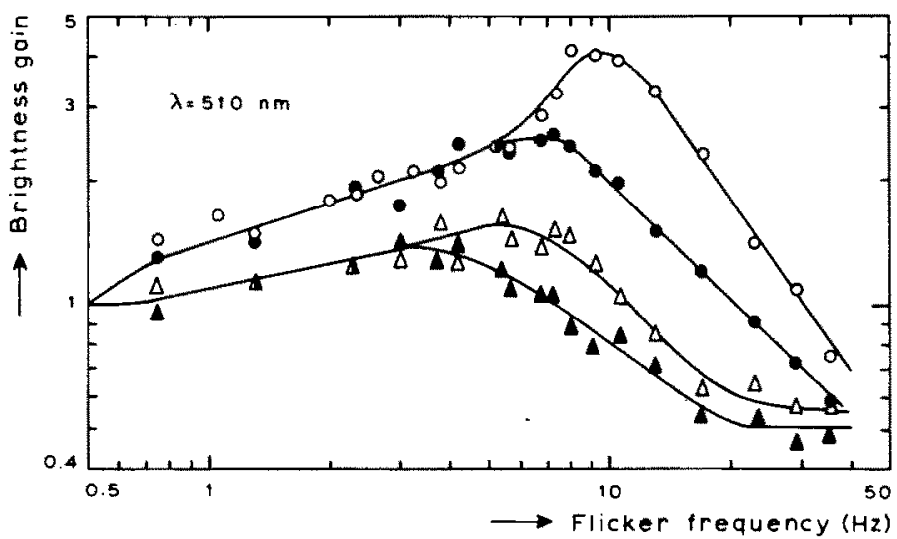

FrG. 3. Brightness enhancement dependent on retinal illuminance at $\lambda=510 \mathrm{~nm}-\mathrm{O}-\mathrm{O}-4800$ troland; $-1-480 \mathrm{td} ;-\Delta-\Delta-48 \mathrm{td} ;-\Delta-4,8 \mathrm{td}$. Obs $\mathrm{H}$.

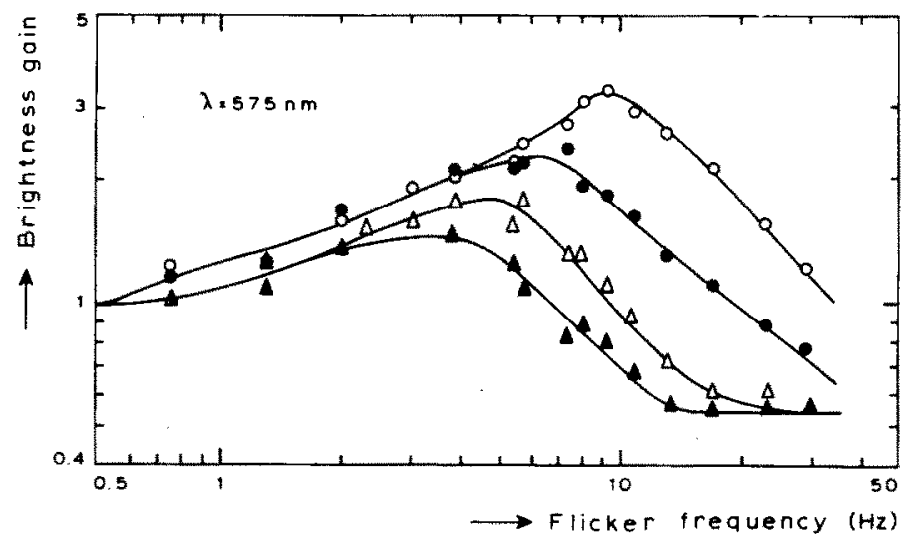

FIG. 4. Brightness enhancement dependent on retinal illuminance at $\lambda=575 \mathrm{~nm}-\mathrm{O}-\mathrm{O}-4800$ troland; $--480 \mathrm{td} ;-\Delta-\Delta-48 \mathrm{td} ;-\Delta 4,8$ td. Obs $\mathrm{H}$. 
RAAB et al. (1962), and AiBA and Stevens (1964) have shown the same relationship in the Broca-Sulzer effect.

In addition to the above mentioned wavelength series of 476,510 and $575 \mathrm{~nm}$, observer $M$ carried out some experiments at $\lambda=491,560,598$ and $625 \mathrm{~nm}$. The retinal illuminance was 4800 troland. The Bezold-Brücke effect was not significantly different for the wavelengths used. The average curve for observer $M$ is drawn in Fig. 5. The standard deviation

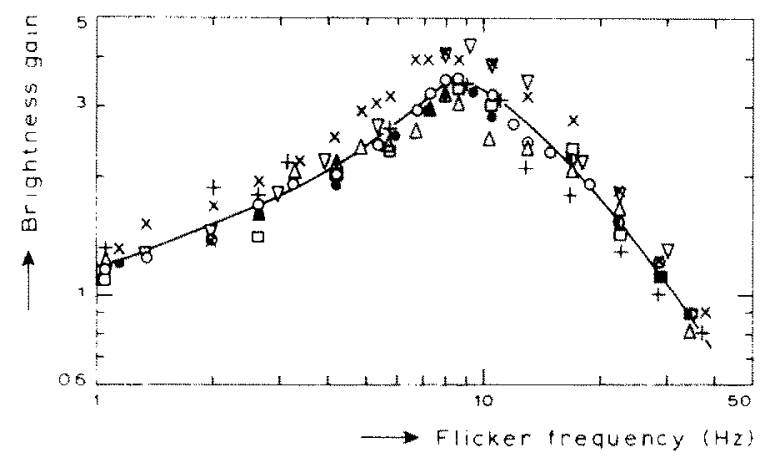

FIG. 5. Brightness enhancement at 4800 troland for different wavelengths $\bigcirc 625 \mathrm{~nm} ; \square 598 \mathrm{~nm}$;

$\Delta 575 \mathrm{~nm} ;+560 \mathrm{~nm}: \times 510 \mathrm{~nm} ; 491 \mathrm{~nm} ; \nabla 476 \mathrm{~nm}$. Obs M.

of these data is in the order of 10 per cent. This means that the spectral composition has virtually no effect upon the Brücke-Bartley phenomenon. To cite Stainton: "The rise of visual sensation is primarily a function of intensity and not of wavelength". This is therefore in contradiction with the findings of Ball, Bartley, Broca-Sulzer, Piéron and Wasserman, as discussed in the introduction.

\section{b. Hue shift}

Besides an increase in brightness of the intermittent light patch, there is a very distinct hue shift and change of saturation too. We determined the hue shift quantitatively as a function of the flicker frequency, at seven wavelengths. It was not possible, however, to obtain a reliable result with the blue test light at $476 \mathrm{~nm}$. This is probably due to a strong desaturation. The other data are plotted in Fig. 6 . The results, together with the standard

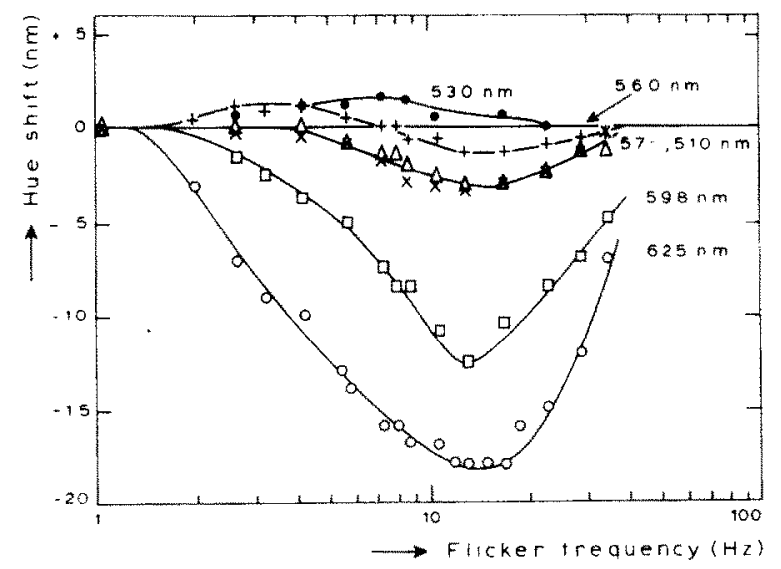

FIG. 6. The hue shift as a function of flicker frequency for several wavelengths. Retinal illuminance 4800 td. Obs $M$. 
deviations, are also presented in Table 1 . Except for $\lambda=510 \mathrm{~nm}$ and partly for $\lambda=560 \mathrm{~nm}$ these facts reveal a hue shift towards yellowish green.

Table 1. HuE SHIFT (IN nm) AS A FUNCTION OF THE FLICKER FREQUENCY.

STANDARD DEVIATIONS IN PARENTHESES. DATA ARE FOR OBSER VER M

\begin{tabular}{|c|c|c|c|c|c|c|}
\hline \multirow{2}{*}{$\frac{\text { Freq. }}{(\mathrm{Hz})}$} & \multicolumn{6}{|c|}{ Wavelength } \\
\hline & $625 \mathrm{~nm}$ & $598 \mathrm{~nm}$ & $575 \mathrm{~nm}$ & $560 \mathrm{~nm}$ & $530 \mathrm{~nm}$ & $510 \mathrm{~nm}$ \\
\hline 0 & 0 & 0 & 0 & 0 & 0 & 0 \\
\hline $1 \cdot 1$ & 0 & 0 & 0 & 0 & $+0.5(0.2)$ & 0 \\
\hline $2 \cdot 7$ & $-7 \cdot 1(1 \cdot 3)$ & $-1.5(0.4)$ & $0.0(0.2)$ & $+1.3(0.2)$ & $+0.5(1.1)$ & $-0.3(0.1)$ \\
\hline $3 \cdot 2$ & $-9.0(1.6)$ & $-2.5(0.4)$ & - & $+0.9(0.2)$ & - & - \\
\hline $4 \cdot 2$ & $-10 \cdot 2(1.8)$ & $-3.7(0.5)$ & $0.0(0.4)$ & $+1.2(0.2)$ & $+1.0(0.3)$ & $-0.5(0.2)$ \\
\hline 5.8 & $-14 \cdot 1(2 \cdot 2)$ & $-5.0(0.7)$ & $-0.8(0.2)$ & $\begin{array}{r}0.6(0.2) \\
\end{array}$ & $\begin{array}{r}1.3(0.8) \\
+\end{array}$ & $-1.0(0.3)$ \\
\hline $7 \cdot 3$ & $-16.0(2.6)$ & $-7.5(1.0)$ & $-1.5(0.3)$ & $0.0(0.2)$ & $+1.7(0.4)$ & $-2.0(0.4)$ \\
\hline $8 \cdot 0$ & $-16.0(2.8)$ & $-8.5(1 \cdot 1)$ & $-1.5(0.3)$ & $0.0(0 \cdot 1)$ & - & - \\
\hline 8.7 & $-17.0(2.7)$ & $-8.5(1 \cdot 1)$ & $-2.0(0.3)$ & $0.6(0.2)$ & $+1 \cdot 3(0 \cdot 3)$ & $-3.0(0.3)$ \\
\hline $10 \cdot 7$ & $-17.0(2.7)$ & $-11.0(1.4)$ & $-2.5(0.4)$ & $-0.6(0.2)$ & $\begin{array}{r}0.5(0.4) \\
+\end{array}$ & $-3.3(0.4)$ \\
\hline $13 \cdot 0$ & $-18.0(2.9)$ & $-12.5(1.6)$ & $-3.0(0.4)$ & $1.3(0.2)$ & - & $-3.5(0.5)$ \\
\hline $17 \cdot 0$ & $-18.0(2.8)$ & $-10.5(1.3)$ & $-3.0(0.4)$ & $-1.3(0.2)$ & $+0.5(0.3)$ & $-3.3(0.4)$ \\
\hline $23 \cdot 0$ & $-15.0(2.4)$ & $-8.5(1.1)$ & $-2.3(0.3)$ & $0.9(0.2)$ & 0 & $-2.5(0.4)$ \\
\hline $29 \cdot 0$ & $12 \cdot 0(2 \cdot 1)$ & $-7.0(0.9)$ & $-1.5(0.3)$ & $0.6(0.2)$ & 0 & $-1.5(0.4)$ \\
\hline $35 \cdot 0$ & $-7.2(1.3)$ & $-5.0(0.7)$ & $-1.5(0.3)$ & $0.4(0.1)$ & 0 & $-0.5(0.3)$ \\
\hline
\end{tabular}

The first explanation one is thinking of is of course the Bezold-Brücke effect. This effect is known as the change in hue when the luminance of a steady light patch is varied. Looking at an intermittent light source we observe a variation of brightness---although the physical energy distribution remains the same. The question arises also whether the Bezold-Brücke effect can give a quantitative explanation of the Brücke-Bartley hue shift or not. To test this assumption some data are needed about the Bezold-Brücke hue shift, measured in the same experimental setup. We therefore removed the rotating disk and increased the luminance of the test light up to six times that of the reference light patch. At a fixed luminance difference we changed the wavelength of the monochromator until the hues of both stimuli matched.

The measurements were repeated for seven other reference wavelengths. The negative values of the measured hue shifts are plotted in Fig. 7. Thus a positive change of hue in this plot means that the hue of the test light is shifting towards longer wavelengths, when the luminance of this light patch is increased. No hue shift was observed at $575 \mathrm{~nm}, 491 \mathrm{~nm}$ and $476 \mathrm{~nm}$. In Fig. 8 the Bezold-Brücke shift is drawn for an increase in luminance by a factor four. This function shows features that are common to previous measurements of this effect: PURDY (1931), BOYNTON and GORDON (1965), LURIA (1967), JACOBS and WASCHER (1967), VAN DER WILDT and BOUMAN (1968). No shift was recorded in our measurements in the blue part of the spectrum.

Comparing Figs. 6 and 7 we see that the Bezold-Brücke effect alone cannot give a quantitative explanation of the observed hue shift at intermittent light stimulation. There seems to be an extra hue shift towards shorter wavelengths. This is clearly demonstrated at $\lambda=575 \mathrm{~nm}$. This is an invariant point for the Bezold-Brücke shift. But because of the brightness enhancement of the flickering light, it is now shifting towards green. The hue shift at $598 \mathrm{~nm}$ and $625 \mathrm{~nm}$ is also much greater than one could expect on a basis of the measured Bezold-Brücke effect. 


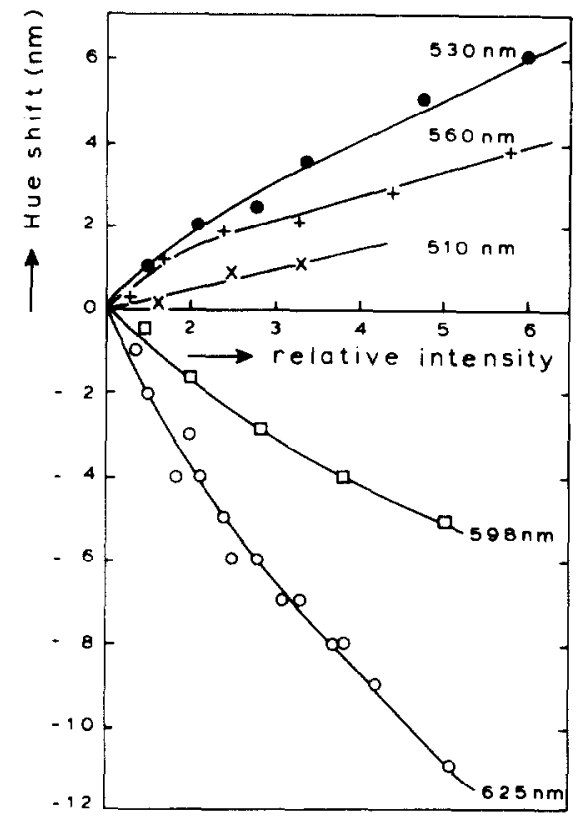

Fig. 7. The hue shift according to the Bezold-Brücke effect for several wavelengths. Obs M.

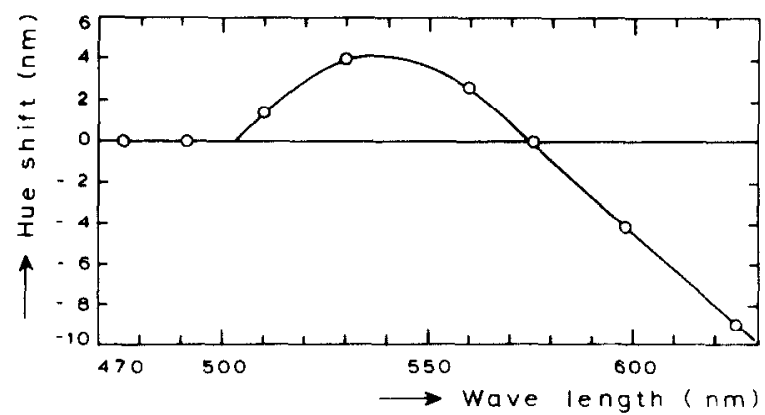

Fig. 8. Bezold-Brücke hue shift. Luminance of the test light patch four times that of the reference light patch. Obs M.

\section{c. Speculations about the hue shift}

As discussed before we distinguish two effects (a) the Bezold-Brücke phenomenon (b) an extra hue shift towards shorter wavelengths, depending on the flicker-frequency.

WALRAVEN and LeEBEEK (1964) have shown a basic phase shift between the red and green colour systems. They found differences in latencies of about $30 \mathrm{msec}$. We suggest that the extra hue shift is possibly due to these phase shifts.

We restrict our speculative calculation to the red $(R)$-green $(G)$ colour system, assuming that the ratio $R: G$, in which $R$ and $G$ are the quanta inputs in the red and green receptor systems, is unique to the apparent colour sensation. For sinusoidally modulated light the input in both systems is therefore:

$$
\begin{array}{lll}
R=-R o\left(\sin \left(\omega t: \varphi_{1}\right)\right. & +1) \\
G & G_{0}\left(\sin \left(\omega t+\varphi_{2}\right)\right. & 1)
\end{array}
$$

The apparent hue, averaged over one cycle, is governed by the chromatic response:

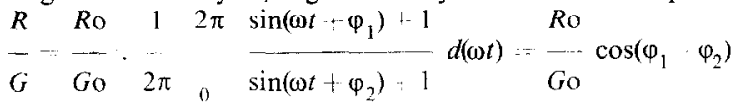


Since $\cos \varphi<1$, this means that at increasing phase difference between the red and green colour systems the ratio $R / G$ is decreasing. This implies a hue shift towards green!

In a theoretical analysis of the Bezold-Brücke effect, WALRAVEN $(1961,1962)$ described this effect on a basis of saturation differences in the stimulus-response relation for each of the receptor systems. So the ratio $R / G$, when not equal to one, tends with increasing intensity to change towards one. Red and green change thus towards yellow if the latter is produced by equal stimulation of the red and green system. We may describe the BezoldBrücke effect therefore as:

$$
\frac{R}{G}=\frac{f_{1}(I) \cdot R_{0}}{f_{2}(I) \cdot G_{0}} \text {, where } f_{1}(I) \text { is the increase in } R_{0} \text {, at the intensity } I \text {, for a fixed luminance increment } \Delta I \text {. Suppose }
$$

we are dealing with a red-coloured stimulus, i.e. $R_{0}>G_{0}$. Increasing the luminance of this stimulus the response of the red channel $\left(R_{0}\right)$ will be saturated much faster than that of the output of the green channel $\left(G_{0}\right)$. This means that $f_{1}(h)<f_{2}(l)$, so that for a fixed luminance increment the increase in the response of the red system is less than the increase in the green system. The functions $f_{1}(I)$ and $f_{2}(I)$ describe this saturation effect for the red and green colour channels respectively. At a fixed wavelength $\lambda_{0}$ only the ratio of these functions $f_{1}(n)$ and $f_{2}(h)$ is important. We may write therefore:

$$
\frac{R}{G}=f_{0}(I) \frac{R_{0}}{G_{0}}
$$

Proceeding from the average brightness enhancement as a function of flicker frequency (Fig. 5), we constructed the hue shift according to the Bezold-Brücke effect by means of Fig. 7. At a reference wavelength $\lambda_{0}$ and a fixed frequency $v$ this calculated hue shift may be $\Delta \lambda_{0}$. With PITT's (1944) sensitivity curves, as revised by WALRAVEN and Bouman (1966), we transformed these wavelengths into the units of $R$ and $G$. Thus $\lambda_{0} \rightarrow\left(R_{0}, G_{0}\right)$ and $\Delta \lambda_{0} \rightarrow\left(\Delta R_{0}, \Delta G_{0}\right)$. Next we calculated the value of $f_{0}(I)$ from the relation:

$$
f_{\circ}(n)=\frac{R}{G} \cdot \frac{G_{\diamond}}{R_{\circ}}=\frac{R_{\circ}+\Delta R_{\circ}}{G_{\diamond}+\Delta G_{\circ}} \cdot \frac{G_{\circ}}{R_{\circ}}
$$

We made these calculations for all frequencies used (at a fixed wavelength $\lambda_{0}$ ). This yields finally an empirical relation between $f_{0}(I)$ and the frequency.

In addition to the Bezold-Brücke effect we assumed an extra hue shift owing to the phase shift in the red and green colour channels. This may be written in the analytical form:

$$
\frac{R}{G}=f_{0}(I) \cdot \frac{R_{\circ}}{G_{0}} \cdot \cos \left(\varphi_{1}-\varphi_{2}\right)
$$

The hue shift for the total Brücke-Bartley effect is plotted in Fig. 6 . We transform the hue shift $d \lambda_{0}$ (using the same reference wavelength $\left.\lambda_{0}\right)$ into $\left(d R_{0}, d G_{0}\right)$.

This procedure was repeated for every frequency. The phaseshift $\Delta \varphi$ as a function of the frequency may be calculated from the following expression :

$$
\cos (\Delta \varphi)-\frac{R}{G}-\frac{1}{R_{0}} \cdot \frac{R_{0}(I)}{R_{0}+d R_{0}} G_{0}+d G_{0} \cdot \frac{1}{R_{0} f_{0}(I)}
$$

In the case that the Bezold-Brücke hue shift is as great as the Brücke-Bartley shift, i.e. $\left(\Delta R_{0}, \Delta G_{0}\right)=\left(d R_{0}, d G_{0}\right)$, the phase difference $\Delta \varphi$ is zero. All these calculations were repeated for three other wavelengths.

Our hypothesis now enables us to obtain the curves drawn in Fig. 9. Since there is no contribution of the blue cone system to colour vision in this part of the spectrum, the phase shift should be the same for each wavelength. This is obviously not the case though all curves have the same tendency. But as we remarked already there is still another difficulty. Besides the change in hue there is a change in saturation too. According to Newhall et al. (1943), the hue in the red end of the spectrum is shifting towards longer wavelengths when the saturation degree is decreased. Desaturation caused no hue shift in the yellow, including $560 \mathrm{~nm}$ and $575 \mathrm{~nm}$. We observed a certain amount of desaturation at the Brücke-Bartley effect. This implies that correction for the change in saturation will decrease the total hue shift for the red colours (598 nm and $625 \mathrm{~nm}$ ). It will therefore decrease the phase-shift for both colours too. We may expect also that the "saturation correction" curves for $625 \mathrm{~nm}$ and $598 \mathrm{~nm}$ from Fig. 9 will come closer to the yellow curves, and because of this our speculation may become more reliable.

Finally a remark about the latency time differences in both colour systems. As follows 


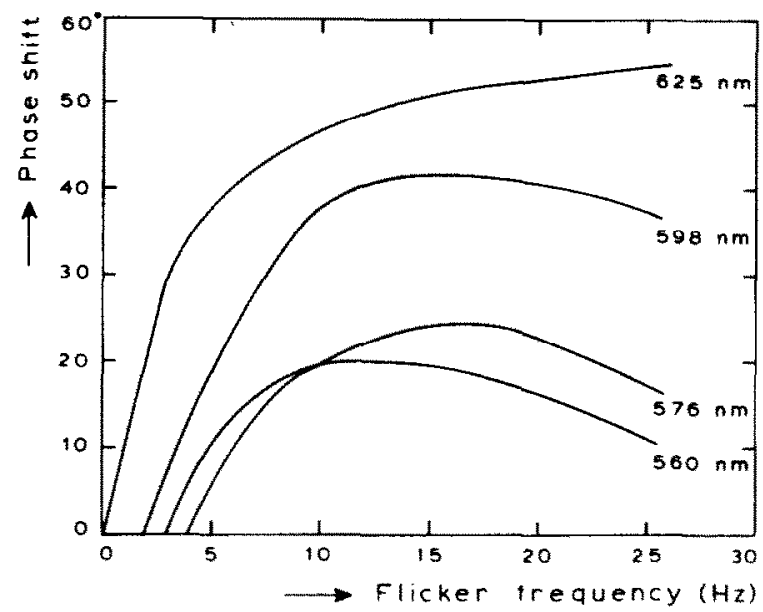

FIG. 9. Phase shift between the red and green colour signals as a function of frequency for four wavelengths.

from Fig. 9, the mean slope of the four curves between zero and $7 \mathrm{~Hz}$ is $6 \frac{1}{4}^{\circ}$ per sec. That means a difference in latencies of $17 \mathrm{msec}$. This value is of the same magnitude as Walraven and Leebeek have found.

\section{d. Target size}

We made some measurements in which the dia. of the steady light patch remained $3: 4$ and the dia. of the flickering test light was decreased from $3 \frac{1}{4}$ down to $5^{\prime}$. The distance between the centers of the two stimuli remained $7 \cdot 35^{\circ}$. The fixation point ( $24 \mathrm{~min}$ of arc) was opaqued now. The wavelength of the stimulus was $575 \mathrm{~nm}$. The results are presented in Fig. 10. As RABelo and GrüsSER (1961) have shown, a decrease of the test field caused not only a decrease in the brightness enhancement but also in the flicker frequency where the Brücke--Bartley effect is maximal. For dia. sizes of $24^{\prime}$ and smaller, there is no change in this particular flicker frequency. It seems that the whole curve, including the Talbot plateau, is shifted upwards. We assume that this typical character is due to some contrast effect. Lateral inhibition may be responsible for this.

VON BÉKÉSY (1960) proposed a simple model of lateral inhibition by means of a "neural unit". Applying his unit, which is one-dimensional in space, to our case we expect that the brightness of the little test spot is increasing when the radius of the test field decreases below the width of the refractive area of this neural unit. When the radius of the light patch is approaching zero the brightness gain will be, according to this model, $\frac{S / R}{S / R-1}$. This ratio $S / R$ is the sensation area divided by the inhibition area.

We shall illustrate this by means of Fig. 11. The data plotted in this figure are taken from a vertical cross section in Fig. 10, at $0 \mathrm{~Hz}$ (with the addition of some measurements at 10 . 19, 28 and $41 \mathrm{~min}$ of arc). The crosses drawn in this figure are from similar measurements at $\lambda=476 \mathrm{~nm}$. The solid line is the best fit for the theoretical curve based on von Békésy's model. This brightness of the test light is increasing below a visual angle of $26^{\prime}$. The width of the refractive area is therefore $\frac{1}{2} \times 26^{\prime}=13^{\prime}$. The brightness gain for an infinitesimal small light patch would be $2 \cdot 35$. This means that the ratio $S / R$ appears to be $1 \cdot 74$. These values are in agreement with the finding of von Békésy.

WESTHEIMER (1967) measured the increment threshold for small brief stimuli. He too 


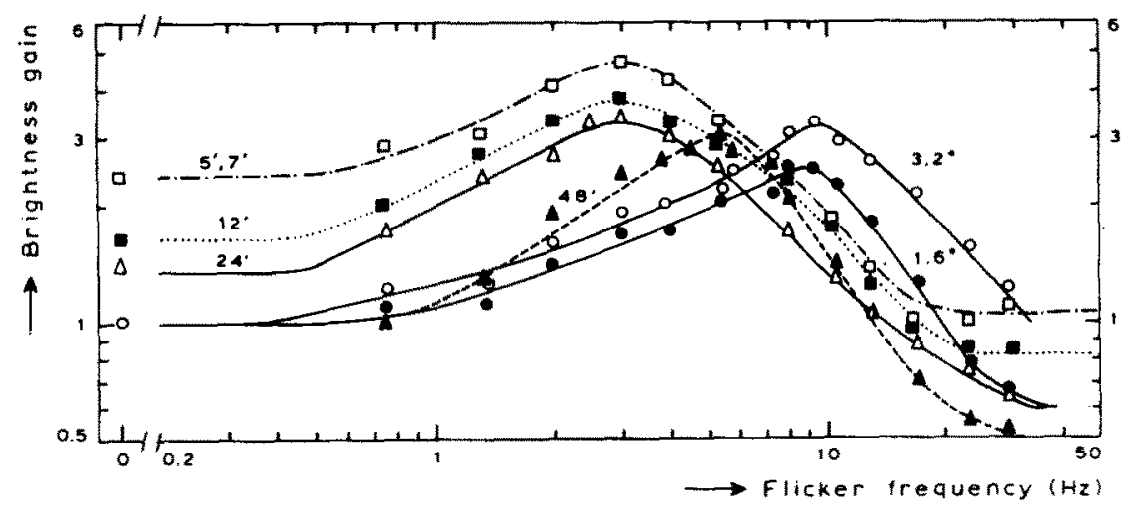

FiG. 10. Brightness enhancement dependent on the target size. Retinal illuminance 4800 td. Obs $H$.

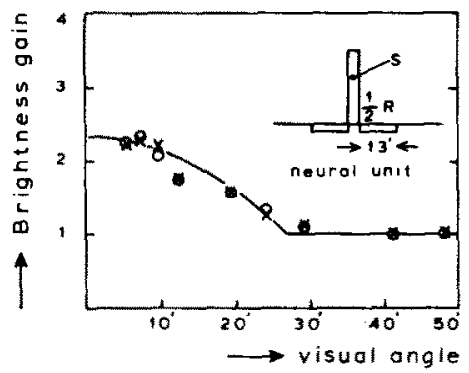

Fic. 11. Brightness enhancement under steady conditions $(0 \mathrm{~Hz}$ flicker) as a function of the target size. The solid line is drawn according to the prediction of von Békésy's neural unit model. Width of the refractive area is $13^{\prime}, S / R=1,74$.

shows an increase in the threshold as the diameter of the ilfummated patch is decreased down to $5 \mathrm{~min}$ of arc. But he argues that this threshold raising effect is not due to the "border effect" of the light patch. His conclusion differs from the quantitative agreement of our data with the theory of von Békésy. As was to be expected the increment threshold will drop after he decreased the dia. below $5^{\prime}$ to $2 \cdot 5^{\prime}$. Although we did not measure this we may also expect that the brightness gain will drop somewhere below $5 \mathrm{~min}$ of arc, owing to the diffraction and scattering of light.

\section{REFERENCES}

AibA, T. S. and Stevens, S. S. (1964). Relation of brightness to duration and luminance under light-and dark adaptation. Vision Res. 4, 391-401.

BALL, R. J. (1964). An investigation of brightness enhancement tendencies. Am. J. Optom. 41, 333-361.

BALL, R. J. and BARTLEY, S. H. (1966). Changes in brightness-index, saturation and hue produced by luminance-wavelength-temporal interactions. J. opt. Soc. Am. 56, 695-699.

BARTLEY, S. H. (1961). A clarification of some of the procedures and concepts involved in dealing with the optical pathway. The Visual System. (edited by R. Jung) Freiburg Symposium (1961).

BÉkÉsy, G. voN (1960). Neural inhibitory units of the eye and skin. Quantitative description of contrast phenomena. J. opt. Soc. Am. 50, 1060-1070.

Bovnton, R. M. and GoRdon, J. (1965). Bezold-Brücke hue shift measured by colornaming technique. J. opt. Soc. Am. 55, 78-86.

BRÜCKE, E. (1864). Ueber den Nutzeffekt intermittirender Netzhautreizungen. Sitzungs. ber. K. Acad. Wiss. Wien $49,128-153$.

Broca, D. and Sulzer, A. (1903a). Sensation lumineuse en fonction du temps pour les lumières colorées; techniques et resultats. C. r. hèbd. séanc. Acad. Sci. Paris 137, 944-946. 
Broca, D. and Sulzer, A. (1903b). Role du temps dans la comparison des états lumineux en lumière colorée. C. r. hèbd. séanc. Acad. Sci. Paris 137, 977-979.

Broca, D. and Sulzer, A. $(1 \cdot 03 \mathrm{c})$. La sensation lumineuse en fonction du temps pour les lumières colorées discussion des resultats. C. r. hébd. séanc. Acad. Sci. Paris 137, 1046-1049.

JACOBS, G. H. and WASChER, T. C. (1967). Bezold-Brücke hue shift: further measurements. J. opt. Soc. Am. 57, $1155-1156$

LURIA, S. M. (1967). Color-name as a function of stimulus-intensity and duration. Am. I. Psychol. 80, 14-27.

Newhall, S. M., Nickerson, D. and JudD, D. B. (1943). Final report of the O.S.A. subcommittee on the spacing of Munsell colors. J. opt. Soc. Am. 33, 385-418.

Piéron, H. (1929). Lois d'établissements du chroma des impressions lumineuses. C. r. hèbd. séanc. Acad. Sci. Paris 189, 194-197.

Pits, F. H. G. (1944). The nature of normal trichromatic and dichromatic vision. Proc. R. Soc. B 132, $101-117$.

Purdy, D. McL. (1931). Spectral hue as a function of intensity. Am. J. Psychol. 43, 541-559.

RAAB, D. (1962). Magnitude estimation of the brightness of brief foveal stimuli. Science, N. Y. 135, 42-43.

Rabelo, G. and GrüsSNER, O. J. (1961). Die Abhängigkeit der subjektieven Helligkeit intermittierender Lichtreize von der Flimmerfrequenz. Untersuchungen bei verschiedene Leuchtdichte und Feldgrösse. Psychol. Forschung. 26, 299-312.

ShePPARd, J. J. JR. (1968). Human Color Perception. Elsevier, New York.

Stainton, W. H. (1928). The phenomenon of Broca and Sulzer in foveal vision. J. opt. Soc. Am. 16, 26-40.

Stevens, S. S. (1966). Duration, luminance and brightness exponent. Percept. Psychophys. 1, 96-100.

VARú́, D. (1964). Der Einfluss sinusförmiger Leuchtdichteänderungen auf die mittlere Pupillenweite und auf die subjektieve Helligkeit. Kybernetik 2, 3343.

VERINGA, F. (1961). Enige natuurkundige aspecten van het zien van gemoduleerd licht. Thesis, University of Amsterdam.

Walraven, P. L. (1961). On the Bezold Brücke phenomenon. J. opt. Soc. Am. 51, 11131116.

WaLraven, P. L. (1962). On the mechanisms of colour vision. Thesis, University of Utrecht.

Walraven, P. L. and Bouman, M. A. (1966). Fluctuation theory of colour discrimination of normal trichromats. Vision Res. 6, 567-586.

Walraven, P. L. and Leebeek, H. J. (1964). Phase shift of sinusoidally alternating colored stimuli. J. opt. Soc. Am. 54, 78-82.

W ASSERMAN, G. S. (1966a). Brightness enhancement and opponent-colors theory. Vision Res. 6, 689-699.

WASSERMAN, G. S. (1966b). Brightness enhancement in intermittent-light, variation of luminance and light-darkratio. J. opt. Soc. Am. 56, 242-250.

Westheimer, G. (1967). Spatial integration in human cone vision. J. Physiol. 190, 139-154.

Wildt, G. J. van Der and Bouman, M. A. (1968). The dependence of Bezold-Brücke hue shift on spatial intensity distribution. Vision Res. 8, 303-313.

\begin{abstract}
The brightness enhancement of flickering light was measured as a function of illuminance, wavelength and target size. Data obtained with stimuli of seven different wavelengths show that the spectral composition has virtually no effect upon this Brücke-Bartley effect. When the illuminance was decreased the frequency at which the enhancement was found to be maximal, decreased too. In addition to the brightness gain the apparent hue shift was determined too. This shift might be explained by the Bezold-Brücke phenomenon and a possible phase shift between the different colour signals. Von Békésy's model of a neural unit accounts for some of the details when the target size is decreased below $30 \mathrm{~min}$ of arc.
\end{abstract}

Résumé-La luminosité apparente d’une lumière papillotante est mesurée en fonction de la luminance, la longueur d'onde et la dimension du test. Les données obtenues avec sept longueurs d'onde diffèrentes indiquent que la composition spectrale n'a pas d'effet sur le phénomène de BrückeBartley. Quand on diminue la luminance, la fréquence, près de laquelle la luminosité est maximale, diminue aussi. En dehors de la luminosité le changement de couleur était mesuré aussi. Ce changement est expliqué par-le phénomène de Bezold-Brücke et un changement eventuel de phase entre les signaux colorés différents. L'inhibition latérale, comme présentée dans le modèle de von Békésy, rend compte de quelques particularités, quand les dimensions du test sont diminuées sous un angle de trente minutes. 
Zusammenfassung-Die subjektive Helligkeit von Flimmerlicht wurde untersucht in Abhängigkeit von der Beleuchtungsstärke, Wellenlänge und FeldgröBe. Messungen an Lichtreizen mit sieben verschiedenen Wellenlängen zeigen, da $B$ die spektrale Zusammensetzung keine Wirkung auf den Brücke-Bartley-Effekt hat. Wenn man die Beleuchtungsstärke vermindert, verringert sich auch die Flimmerfrequenz, bei der die Helligkeitsverstärkung maximal ist. Außer dieser Verstärkung wurde auch die Farbverschiebung gemessen. Diese Verschiebung wurde auf das Bezold-Brücke-Phänomen und auf eine mögliche Phasenverschiebung zwischen den verschiedenen Farbrezeptoren zurückgeführt. Von Bekesys Modell der lateralen Hemmung erklärt einige der Einzelheiten bei Feldgrößen unter 30 Winkelminuten.

Резюме - Была измерена субъективная яркость (усиление) мигающего светого стимула в зависимости от интенсивности, длины волны света и величины поля. Данные добыванные для 7 различных длин волн показывают что спектральный состав стнмула не действует на "Брюке-Бартли эффект". Снижая интенсивность стимула, частность мнгания, при которой ускление достигнет максимум, тоже снижается. Одновременно с усилением измерен был сдвиг в восприятии цветого тона. Можно объявлять этот сдвиг на основании явления Бецолда-Брюке и возможного разного сдвига фаз различных рецепторов цветов. Модель Вон Бекеши о нервном элементе объясняет количественно некоторые особенности усиления субъективной яркости прн величннах поля малее 30 минут угла зрення. 